\title{
PEMBAGIAN HARTA BERSAMA SETELAH PERCERAIAN (STUDI TERHADAP PUTUSAN MAHKAMAH AGUNG NOMOR 597K/AG/2016)
}

\author{
SHARING ASSISTANCE AFTER DIVORCE (STUDY OF \\ SUPREME COURT DECISION NUMBER 597K/AG/2016
}

\author{
Melia \\ Magister Kenotariatan, Fakultas Hukum, Universitas Syiah Kuala \\ email : lia.melia2112@gmail.com \\ Muzakkir Abubakar \\ Fakultas Hukum, Universitas Syiah Kuala \\ email : muzakkir@unsyiah.ac.id \\ Darmawan \\ Fakultas Hukum, Universitas Syiah Kuala \\ email : darmawan@unsyiah.ac.id
}

\begin{abstract}
Joint assets are a legal consequence after the divorce. The position of joint property after divorce is regulated according to each law, in accordance with the provisions of Article 37 of the Marriage Law. Pursuant to Article 97 of KHI if the marriage is terminated due to divorce, the joint property is divided in two. But in reality based on the Supreme Court Decree No. $597 \mathrm{~K} / \mathrm{Ag} / 2016$, the judge decided the portion received by his ex-wife was greater than his ex-husband. The purpose of this study is to explain the considerations of the Supreme Court judges in the distribution of shared assets after divorce, and the fulfillment of the principles of justice and legal certainty towards the distribution of shared assets after divorce based on the Supreme Court Decision Number 597 K / Ag / 2016. This research uses normative legal research. The results showed that the Supreme Court judge in his decision No. $597 \mathrm{~K} / \mathrm{Ag} / 2016$ based on the principles of justice and social justice did not divide $1 / 2$ (half) the share of shared assets for ex-husbands and for ex-wives, even the Supreme Court judge shared the distribution of shared assets 2/3 for ex wife and 1/3 part for ex-husband with consideration that the ex-wife contributes more in producing joint assets. The decision of the Supreme Court that overrules Article 97 KHI, where the Supreme Court judge felt unfair and disagreed with the Judge of the Aceh Syariah Court considering the greater portion of the wife's share in the acquisition of joint assets in the marriage.
\end{abstract}

Keywords: Shared Assets, Assets Sharing Along with Divorce, Decision of the Supreme Court Number 597K / Ag / 2016.

\begin{abstract}
Abstrak
Harta bersama merupakan suatu akibat hukum setelah terjadinya perceraian. Kedudukan harta bersama setelah perceraian diatur menurut hukumnya masingmasing, sesuai dengan ketentuan Pasal 37 UU Perkawinan. Berdasarkan Pasal 97 KHI apabila putus perkawinan karena perceraian maka harta bersama dibagi dua. Namun dalam kenyataannya berdasarkan Putusan Mahkamah Agung Nomor 597
\end{abstract}


$\mathrm{K} / \mathrm{Ag} / 2016$, hakim memutukan bagian yang diterima oleh bekas isterinya lebih besar dari bekas suaminya. Tujuan penelitian ini adalah untuk menjelaskan pertimbangan hakim Mahkamah Agung dalam pembagian harta bersama setelah perceraian, dan pemenuhan prinsip keadilan dan kepastian hukum terhadap pembagian harta bersama setelah perceraian berdasarkan Putusan Mahkamah Agung RI Nomor 597 K/Ag/2016. Penelitian ini menggunakan jenis penelitian hukum normatif. Hasil penelitian menunjukkan bahwa hakim Agung dalam putusannya Nomor $597 \mathrm{~K} / \mathrm{Ag} / 2016$ berdasarkan asas keadilan dan sosial justice tidak membagi $1 / 2$ (seperdua) bagian harta bersama untuk bekas suami dan untuk bekas isteri, bahkan hakim Agung memutuskan pembagian harta bersama 2/3 untuk bekas isteri dan 1/3 bagian untuk bekas suami dengan pertimbangan bekas isteri lebih berkontribusi dalam menghasilkan harta bersama. Keputusan hakim Agung yang mengenyampingkan Pasal $97 \mathrm{KHI}$, dimana hakim Agung berpendapat kurang adil dan tidak sependapat dengan Hakim Mahkamah Syariah Aceh mengingat porsi andil isteri lebih besar dalam perolehan harta bersama dalam perkawinan.

\section{Kata kunci: Harta Bersama, Pembagian Harta Bersama seletah Perceraian, Putu- san Mahkamah Agung Nomor 597K/Ag/2016.}

\section{PENDAHULUAN}

Setiap orang berkeluarga ada dua hal yang sangat didambakannya, yaitu keturunan dan harta yang halal yang akan didapatkan, karena keturunan menjadi cahaya dan harta menjadi tujuan hidupnya. ${ }^{1}$ Harta dalam perkawinan merupakan modal kekayaan yang dapat dipergunakan oleh suami atau isteri untuk membiayai kebutuhan hidup seharihari suami dan isteri serta anak-ankanya dalam satu rumah tangga. ${ }^{2}$ Harta bersama suami isteri atau yang biasa disebut di Aceh dengan harta seuhareukat, di Minangkabau disebut harta suarang, di Jakarta dinamakan harta pencaharian, di Jawa dinamakan harta gonogini atau barang gono, di Bali disebut drube-garbo, di Kalimantan disebut dengan barang perpantangan, di Sulawesi disebut cakara' dan di Madura disebut ghunaghana ${ }^{3}$ yang artinya adalah harta yang didapat setelah terjadinya akad nikah.

Fahmi Al Amruzi menyatakan harta bersama adalah harta benda yang diperoleh selama masa perkawinan oleh suami isteri, maka termasuk ke dalam pengertian ini adalah semua harta yang diperoleh dari hasil usaha mereka bersama sejak saat perkawinan dilangsungkan yaitu sejak akad nikah diucapkan sampai terjadi perceraian, baik karena cerai mati ataupun cerai hidup, tidak termasuk ke dalamnya harta yang diperoleh oleh masing-masing pihak yang bersumber dari hibah atau warisan ditujukan kepada para pihak dan harta tersebut otomatis menjadi harta pribadi kecuali para pihak menghendaki lain. ${ }^{4}$ Masalah harta bersama merupakan masalah vital yang sering disengketakan oleh pihak suami ataupun isteri pada saat terjadinya perceraian. Disinilah dibutuhkan kejelian dari pada hakim untuk dapat menilai, apakah harta tersebut merupakan harta bersama atau bukan. Demikian halnya dengan contoh kasus yang dikaji dalam penelitian ini, sebagaimana tertuang dalam Putusan Mahkamah Syar'iah Lhoksukon Nomor 168/pdt.9/2014/MS.LSK, di mana sepasang suami isteri bercerai dan dalam putusan tersebut hakim memutuskan mengenai pembagian harta

\footnotetext{
${ }^{1}$ Mahdiah, 2012, Permasalahan Perkawinan dan Kewarisan, Cet. ke-1, Pustaka Panjimas, Jakarta, hlm. 7

${ }^{2}$ Sonny Dewi Judiasih, 2015, Harta Benda Perkawinan, Kajian terhadap Kesetaraan Hak dan Kedudukan Suami dan Isteri atas Kepemilikan Harta dalam Perkawinan, Cet. ke-1, PT Refika Aditama, Bandung, hlm. 7

${ }^{3}$ Budi Setiawan Utomo, 2009, Fiqih Aktual, Gema Insani, Jakarta, hlm.124

${ }^{4}$ Agustina Dewi Putri, 2019, Peralihan Harta Bersama Melalui Hibah Tanpa Izin Salah Satu Pihak Berdasarkan Undang-Undang Nomor 1 Tahun 1974 Dan Kompilasi Hukum Islam, Syiah Kuala Law Journal (SKLJ), Vol. 3, No. 1, hlm. 6
} 
bersama, bahwa bekas suami sebagai penggungat mendapatkan $1 / 3$ bagian dan istri sebagai tergugat mendapatkan $2 / 3$ bagian, namun pihak penggugat (bekas suami) tidak menerima putusan, merasa tidak adil dengan putusan tersebut lalu mengajukan banding ke Mahkamah Syar'iyah Aceh, berdasarkan pengajuan banding tersebut hakim Mahkamah Syar'iyah Aceh mengeluarkan putusan No. 9/pdt.9/2016/MS.Aceh dengan putusan, $1 / 2$ bagian untuk suami dan $1 / 2$ untuk bagian isteri.

Terhadap hasil putusan tersebut pihak tergugat merasa belum adil juga, karena pihak tergugat merasa bahwa lebih banyak hasil yang ia usahakan selama hidup berumah tangga dari pada pihak pengugat (bekas suami), sehingga pihak tergugat mengajukan ketingkat kasasi yaitu ke Mahkamah Agung RI, kemudian keluarlah putusan 597K/ AG/2016 yang menyatakan bahwa suami berhak mendapatkan $1 / 3$ bagian dan istri $2 / 3$ bagian yang hasilnya sama seperti hasil putusan di Mahkamah Syra'iyah Lhoksukon, dari penjelasan kasus tersebut terlihat bahwa terjadi perbedaan putusan di tingkat banding dan kasasi, sehingga menimbulkan persepsi peneliti bahwa ada suatu masalah yang perlu kiranya untuk dikaji kembali tentang ke-3 putusan tersebut. Berdasarkan latar belakang masalah yang telah dikemukakan diatas, maka penulis tertarik untu mengetahui dasar pertimbangan hakim Mahkamah Agung terhadap pembagian harta bersama setelah perceraian berdasarkan putusan Mahkamah Agung RI Nomor 597K/ $\mathrm{Ag} / 2016$. Berdasarkan hasil penelusuran sementara serta pengamatan terhadap berbagai literartur yang berhubungan dengan artikel ini, dalam ruang lingkup akademisi program studi kenotariatan belum pernah diteliti oleh peneliti lain baik dari segi materi maupun objeknya. Namun berdasarkan ruang lingkup nasional, ditemukan beberapa, penelitian yang terdapat kemiripan dengan penelitian yang akan diteliti oleh penulis ini, namun tidak ada satupun yang terfokus pada Putusan Mahkamah Agung Nomor $597 \mathrm{~K} / \mathrm{AG} / 2016$. Berikut penulis menguraikan beberapa penelitian terdahulu tentang pembagian harta bersama setelah berakhirnya perkawinan (perceraian), yaitu penelitian yang dilakukan oleh Nuraini Hikmawati pada tahun 2014 yang yang berjudul tentang Pembagian Harta Bersama Akibat Perceraian di Pengadilan Agama (Studi Putusan No. 0008/Pdt.G/2011/PA.Sm.) dan Penelitian yang dilakukan oleh Angga Budi Saputro pada tahun 2017 tentang Analisis Putusan Hakim tentang Pembagian Harta Bersama (Gono Gini) Akibat Perceraian (Studi Kasus Di Pengadilan Agama Surakarta Tahun 2015). Hasil penelitian menunjukkan bahwa pertimbangan Hakim dalam memutuskan perkara Nomor: 0659/Pdt.G/2015/PA.Ska dan Nomor: 0013/Pdt.G/2015/PA.Ska adalah Pasal 35 ayat (1) Undang-Undang Nomor 1 Tahun 1974 dan Pasal 97 Kompilasi Hukum Islam yang berbunyi: Harta benda diperoleh selama perkawinan menjadi harta bersama. Janda atau duda cerai hidup masing-masing berhak seperdua atas harta bersama sepanjang tidak ditentukan lain dalam perjanjian perkawinan. Pandangan yuridis dan fiqh dalam pembagian harta bersama di Pengadilan Agama Surakarta dalam Putusan Nomor: 0659/Pdt.G/2015/PA.Ska dan Putusan Nomor: 0013/Pdt.G/2015/ PA.Ska Putusan Pengadilan Agama adalah sudah sesuai dengan Undang-Undang Nomor 1 Tahun 1974 dan Kompilasi Hukum Islam Pasal 97. Selanjutnya Penelitian yang dilakukan oleh Ridwan Jamal tentang Harta Bersama Akibat Perceraian dalam KHI dan UU No. 1 tahun 1974. Hasil penelitian menunjukkan bahwa pembagian harta bersama yang diterapkan dan mengacu kepada Kompilasi Hukum Islam khususnya pasal 97 menentukan bahwa janda atau duda yang cerai, masing-masing mendapat seperdua dari harta bersama sepanjang tidak ditentukan lain dalam perjanjian perkawinan. 
Namun hal tersebut dapat berubah dengan adanya pertimbangan lain, misalnya pihak suami isteri bermaksud memberikan harta bersama tersebut kepada anak-anak mereka. Pembagian harta bersama menurut pasal 37 UU Perkawinan, bila terjadi perceraian maka harta bersama diatur menurut hukumnya masing-masing. Karena pasal ini terkesan terlalu dangkal, sehingga diperlukan penjelasan dan undang-undang lain untuk memperkuatnya.

Metode yang digunakan dalam penelitian ini adalah metode penelitian hukum yuridis normatif, ${ }^{5}$ yaitu penelitian yang bertujuan untuk meneliti sistematika hukum, sinkronisasi hukum, sejarah hukum, dan perbandingan hukum. ${ }^{6}$ Pendekatan yang digunakan dalam penelitian ini terutama dilakukan dengan menggunakan pendekatan Undang-undang (statute approach), Pendekatan Kasus (Case Approach) dan pendekatan konseptual (conceptual approach). Sumber-sumber penelitian hukum yang digunakan dalam penelitian ini terdiri dari bahan hukum primer, bahan hukum sekunder, dan bahan hukum tersier. Pengumpulan data dalam penelitian ini dilakukan dengan cara Penelitian Kepustakaan (literature research). Mengenai teknik yang diterapkan dalam pengolahan bahan hukum yang diperlukan dalam penulisan ini adalah melalui teknik telaah kepustakaan. Teknik analisis bahan hukum yang akan digunakan dalam penelitian ini dengan menginterpretasi atau menafsirkan hukum dan mennsinkronisasikan hukum secara vertikal atau horizontal. Dengan teknik ini analisis ditekankan pada analisis kualitatif. Adapun tujuan dari penelitian ini untuk mengetahui dan menjelaskan pertimbangan hakim Mahkamah Agung dalam permbagian harta bersama setelah perceraian berdasarkan Putusan Mahkamah Agung RI Nomor 597K/AG/2016.

\section{PEMBAHASAN}

\section{Pembagian Harta bersama dalam Perkawinan setelah perceraian}

Pada awalnya perkawinan ditujukan untuk mencapai kebahagiaan yang kekal bagi pasangan suami isteri, namun pada kenyataannya banyak faktor penyebab yang memicu masalah dalam kehidupan perkawinan sehingga pasangan tersebut memutuskan jalan yang terakhir dan terbaik adalah dengan cara perceraian. ${ }^{7}$ Setelah terjadi perceraian bukan berarti masalah keluarga tersebut telah selesai semuanya, tapi masih meninggalkan sisa masalah perkawinan seperti anak (jika punya anak) dan harta benda yang diperoleh selama perkawinan, harta yang diperoleh selama masih terikat perkawinan itulah yang disebut harta bersama atau lebih dikenal harta seuharkat, hal ini sangat penting untuk diselesaikan oleh kedua belah pihak demi kebaikan bersama. ${ }^{8}$

Menurut ketentuan pasal 38 Undang-Undang Perkawinan, perkawinan dapat putus karena (a) kematian, (b) perceraian, (c) atas keputusan Pengadilan. Putusnya perkawinan karena kematian sering disebut oleh masyarakat dengan istilah "cerai mati". Sedangkan putusnya perkawinan karena perceraian ada dua sebutan yaitu "cerai gugat" dan "cerai talak". Putusnya perkawinan karena atas keputusan Pengadilan disebut "cerai batal". ${ }^{9}$

\footnotetext{
${ }^{5}$ Titon Slamet Kurnia Dkk, 2013, Pendidikan Hukum, Imu Hukum \& Penelitian Hukum Di Indonesia Sebuah Reorientasi, Pustaka Pelajar, Yogyakarta, hlm. 121

${ }^{6}$ Zainuddin Ali, 2010, Metode penelitian Hukum, Cet. ke-2, Sinar Grafika, Jakarta, hlm. 30

${ }^{7}$ Syaikhul Hakim, 2015, "Reaktualisasi Pembagian Harta Bersama Dalam Mazhab Syafii Dan Kompilasi Hukum Islam Di Indonesia", Akademika, Vol. 9, No. 2, hlm. 45.

${ }^{8}$ Sri Hariati dan Musakir Salat, 2013, Ketidakadilan Pembagian Harta Gono Gini Pada Kasus Perceraian The Injustice Of Distributing Marital Property, Jurnal IUS Kajian Hukum Dan Keadilan, Vol. 1, No. 3, hlm. 2

${ }_{9}$ Sukardi, 2016, "Kajian Yuridis Perjanjian Perkawinan Menurut Kitab Undang-Undang Hukum Perdata, Undang-Undang Nomor 1 Tahun 1974 dan Kompilasi Hukum Islam", Jurnal Khatulistiwa - Journal of Islamic Studies, Vol. 6, No. 1, hlm. 65.
} 
Apabila perkawinan putus akibat perceraian maka muncul permasalahan antara lain mengenai pembagian harta bersama yang pengaturannya menurut hukumnya masing-masing yakni hukum agama, hukum adat, dan hukum-hukum lainnya, artinya harta bersama diatur menurut hukumnya masing-masing. Hal ini mengindikasikan bahwa ketika terjadi perceraian, harta bersama yang diperoleh oleh pasangan suami isteri selama perkawinan dapat diatur dengan menggunakan aturan yang berbeda-beda tergantung pada variasi hukum adat atau hukum lain diluar hukum adat. ${ }^{10}$

Harta bersama merupakan salah satu macam dari sekian banyak harta yang dimiliki seseorang. Dalam kehidupan sehari-hari harta mempunyai arti penting bagi seseorang karena dengan memiliki harta dapat memenuhi kebutuhan hidup secara wajar dan memperoleh status sosial yang baik dalam masyarakat. Namun harta bersama tersebut akan menjadi harta yang tidak lagi dapat disebut sebagai harta bersama ketika telah terjadi cerai mati atau perceraian.

Pembagian harta bersama juga tidak dilakukan pembagian secara sembarangan, tetapi pembagian harta bersama memiliki aturan-aturan yang diatur dalam Undang-Undang Perkawinan, serta diatur di dalam Kompilasi Hukum Islam, di mana pembagian harta bersama itu dilakukan melalui proses sidang di Pengadilan Agama yang harus dihadiri oleh kedua belah pihak yang bersangkutan (Suami-Istri). ${ }^{11}$ Pembagian harta bersama akibat dari adanya perceraian, cara pembagiannya biasanya adalah dengan membagi rata, masing-masing (suami dan istri) mendapat 1/2 (setengah) bagian dari harta gonogini tersebut. Hal ini sesuai dengan ketentuan dalam Pasal 97 KHI dan selaras dengan ketentuan dalam KUH Perdata. ${ }^{12}$

Percampuran kekayaan adalah mengenai seluruh activa (harta atau kekayaan baik berupa uang atau benda lain yang dapat dinilai dengan uang) dan passiva (saham atau kekayaan yang tidak memberikan keuntungan). Percampuran ini bisa mencakup harta bawaan dan/atau harta perolehan ke dalam perkawinan yang akhirnya menjadi harta bersama. Sesungguhnya percampuran kekayaan ini bukanlah masalah selama menjadi kesepakatan antara suami istri. ${ }^{13}$

Biasanya sengketa harta bersama ini akan timbul jika terjadi perselisihan antara suami istri atau perceraian. Terlebih bila tidak ada perjanjian pemisahan harta dalam perkawinan. Kadangkala, masing-masing pihak mengklaim atas harta bersama menjadi harta bawaan atau harta perolehan. Atau, pihak istri dirugikan dan mengalami ketidakadilan dalam pembagian harta bersama berdasarkan putusan pengadilan. Inilah cikal bakal terjadinya perselisihan harta bersama. ${ }^{14}$

Pembagian harta bersama bagusnya dilakukan secara adil, sehingga tidak menimbulkan ketidakadilan antara mana yang merupakan hak suami dan mana hak isteri. Menurut Erna Wahyuningsih dan Putu Samawati menjelaskan bahwa cara mendapatkan harta bersama, sebagai berikut : Pembagian harta bersama dapat diajukan bersamaan dengan saat mengajukan gugat cerai dengan menyebutkan harta bersama dan bukti-bukti bahwa harta tersebut diperoleh selama perkawinan dalam "posita" (alasan mengajukan gugatan). Permintaan pembagian harta disebutkan dalam petitum (gugatan). Pembagian

${ }^{10}$ Evi Djuniarti, 2017, Hukum Harta Bersama Ditinjau Dari Perspektif Undang-Undang Perkawinan Dan KUHPerdata, Jurnal Penelitian Hukum DE JURE, Vol. 17 No. 4, hlm. 8

${ }^{11}$ Ibid, hlm. 2

${ }^{12}$ Eni C. Singal, 2017, Pembagian Harta Gono-Gini Dan Penetapan Hak Asuh Anak Akibat Perceraian Berdasarkan Undang-undang Nomor 1 Tahun 1974, Lex Crimen, Vol. 6, No. 5, hlm. 2

${ }^{13}$ Sri Hariati dan Musakir Salat, Op. Cit, hlm 2

${ }^{14}$ Ibid. 
harta bersama diajukan setelah adanya putusan perceraian, artinya mengajukan gugatan atas harta bersama. Bagi yang beragama Islam gugatan atas harta bersama diajukan ke pengadilan agama di wilayah tempat tinggal isteri. Untuk non-Islam gugatan pembagian harta bersama diajukan ke pengadilan negeri tempat tinggal termohon. ${ }^{15}$

\section{Pertimbangan hakim dalam pembagian harta bersama setelah perceraian ber- dasarkan putusan Mahkamah Agung RI Nomor 597 K/Ag/2016}

Duduk perkara kasus pembagian harta bersama tingkat kasasi dalam putusan Mahkamah Agung RI Nomor $597 \mathrm{~K} / \mathrm{Ag} / 2016$ ini adalah penggugat merupakan suami sah dari tergugat, perkawinan dilangsungkan pada tahun 1995. Berdasarkan Putusan Mahkamah Syariah Lhoksukon tanggal 2 Desember 2013 Nomor 338/Pdt.G/2013/ MS-LSK dan Akta Cerai tanggal 28 Januari 2014 Nomor AC: 31/AC/2014/MS-Lsk, perkawinan penggugat dengan tergugat telah berakhir. Selama penggugat menikah dengan tergugat todak mempunyai keturunan, melainkan harta bersama (seuharkat).

Setelah melalui beberapa tahap persidangan, baik melalui tahap Mahkamah Syariah Lhoksukon, banding pada Mahkamah Syariah Aceh, dan yang terakhir tingkat kasasi pada Mahkamah Agung, maka permohonan kasasi tersebut secara formal dapat diterima dengan alasan-alasan kasasi pada pokoknya ialah : Bahwa pemohon kasasi/semula terbanding tidak dapat menerima Keputusan Mahkamah Syariah Aceh tersebut dengan baik dan untuk itu Pemohon Kasasi/semula terbanding telah menyatakan mohon pemeriksaan dalam tingkat kasasi atas keputusan Mahkamah Syariah Aceh tersebut pada tanggal 14 Maret 2016.

Bahwa majelis hakim tingkat banding yang membatalkan putusan Mahkamah syariah Lhoksukon juga berlaku kurang adil dalam memeriksa, mengadili dan membrikan putusan dalam perkara ini, karena terbukti pertimbangan hukum dan dalil-dalilnya memihak pada termohon kasasi/semula pembanding. Bahwa Majelis Hakim tingkat banding yang membatalkan putusan Mahkamah Syariah Lhoksukon juga berlaku kurang adil dalam memeriksa, mengadili dan memberikan putusan dalam perkara ini, karena terbukti pertimbangan hukum dan dalil-dalilnya memihak kepada termohon kasasi/semula pembanding. Bahwa mengenai pertimbangan Majelis Hakim Syariah Aceh yang menyatakan : "Bahwa meskipun tergugat mengakui obyek gugatan merupakan harta yang diperoleh selama dalam perkawinan dengan penggugat, namun tergugat keberatan dijadikan sebagai harta bersama dengan pengugat dengan alasan harta tersebut diperoleh dari hasil usaha tergugat sendiri sebagai Bidan Desa, sementara penggugat belum ada pekerjaan sama sekali dan sejak tahun 2000 penggugat bekerja sebagai honorer di Bappeda Lhokseumawe dengan dibiayai kebutuhan rumah tangga oleh tergugat, bahkan sampai penggugat menjadi PNS tahun 2007 tidak pernah sama sekali membiayai kebutuhan rumah tangga penggugat lebih memperhatikan dan membantu kebutuhan orang tuanya.

Bahwa mengenai pertimbangan Majelis Hakim Mahmakah Syariah Aceh yang menyatakan : "bahwa tergugat secara klausula tidak mengakui harta yang diperoleh selama perkawinan sebagai harta bersama karena penggugat tidak ada pekerjaan, Majelis Hakim tingkat banding memandang hal tersebut harus dinyatakan keliru, karena obyek gugatan tersebut diperolehnya selama dalam perkawinan penggugat dan tergugat, lagi pula sebagian besar obyek tersebut diperoleh setelah penggugat bekerja baik sebagai

${ }^{15}$ Bernadus Nagara, 2016, Pembagian Harta Gono-Gini atau Harta Bersama Setelah Perceraian Menurut Undang-Undang Nomor 1 Tahun 1974, Lex Crimen, Vol. 5, No. 7, hlm. 2 
honorer maupun sebagai PNS, bahkan sesuai fakta pula ternyata sebagian obyek gugatan terbukti penggugat sendiri terlibat sebagai pihak dalam transaksi jual beli atau pembeliannya oleh penggugat sendiri karenanya alasan dan tidakk diakuainya obyek gugatan tersebut sebagai harta bersama dikarenakan penggugat tidak ada pekerjaan dinyatakan tidak beralasan dan harus ditolak. Bahwa mengenai pertimbangan Majelis Hakim Mahkamah Syariah Aceh yang menyatakan "bahwa dengan demikian maka putusan Mahkamah Syariah Lhoksukon Nomor 168/Pdt.G/2014/Msk-Lsk tanggal 06 Juli 2015 tersebut tidak dapat dipertahankan dan karenanya harus dibatalkan.

Berdasarkan pertimbangan diatas, amar putusan Mahkamah Syariah Aceh harus dibatalkan dan Mahkamah Agung akan mengadili sendiri perkara ini dengan pertimbangan berikut : Bahwa Mahkamah Syariah Aceh dalam putusannya tidak mempertimbangkan tentang tuntutan provisi penggugat/pembanding, sehingga hal tersebut berpengaruh pula terhadap tidak adanya amat tentang tuntutan provisi tersebut. Bahwa pertimbangan Mahkamah Syariah Lhoksukonn tentang tuntutan provisi penggugat/pembanding sudah tepat dan benar, sehingga Mahkamah Agung mengambil alih pertimbangan tersebut sebagai pertimbangan sendiri. Bahwa akan tetapi pertimbangan Mahkamah Syariah Lhoksukon tentang tuntutan provisi penggugat/ pembanding tersebut tidak diikuti dengan adanya amar dalam putusan a quo, sehingga Mahkamah Agung perlu menambahkan amar tentang tuntutan provisi penggugat/ pembanding, sebagaimana akan disebutkan dalam amar putusan dibawah ini. Bahwa penerapan asas contra legem yang dilakukan oleh Mahkamah Syariah Lhoksukon dalam perkara a quo dapat dibenarkan mengingat porsi andil tergugat/terbanding lebih besar dalam perolehan harta bersama dalam perkawinan penggugat/pembanding dengan tergugat/terbanding. Bahwa oleh karena putusan dan pertimbangan Mahkamah Syariah Lhoksukon tentang penerapan asas contra legem dalam perkara a quo sudah benar dan tepat, maka Mahkamah Agung mengambil alih pertimbangan tersebut sebagai pertimbangan sendiri.

Menimbang berdasarkan pertimbangan tersebut diatas, dengan tidak perlu mempertimbangkan alasan kasasi lainnya, menurup pendapat Mahkamah Agung terdapat cukup alasan untuk mengabulkan permohonan kasasi dari permohon kasasi dan membatalkan putusan Mahkamah Syaiah Aceh Nomor 9/Pdt.G/2016/MS-Aceh, tanggal 14 Maret 2016 yan membatalkan putusan Mahkamah Syariah Lhoksukon Nomor 168/Pdt.G/2014/MS-Lsk, tanggal 10 Agustus 2015, serta Mahkamah Agung mengadili sendiri perkara ini dengan amar putusan mengabulkan permohonan kasasi dari pemohon kasasi (pihak Isteri) tersebut. Membatalkan putusan Mahkamah Syariah Aceh Nomor 9/Pdt.G/2016/MS-Aceh, tanggal 14 Maret 2016 M, yang membatalkan putusan Mahkamah Syariah Lhoksukon Nomor 168/Pdt.G/2014/MS-Lsk, tanggal 10 Agustus 2015 M.

\section{Analisa Pertimbangan Hakim Mahkamah Agung dalam Putusan Mahkamah Agung RI Nomor 597 K/Ag/2016}

Berbicara mengenai pertimbangan hakim itu berarti berbicara mengenai yang mengadili perkara tersebut, yang kesemuanya itu dilangsungkan di lembaga peradilan setempat berdasarkan tata cara dan prosedur yang sudah diatur. Untuk yang beragama Islam proses penyelesaianya dilakukan di Pengadilan Agama. Pertimbangan Pengadilan dalam menetapkan suatu keputusan yang adil, dengan menerapkan nilai-nilai hukum yang standart, seperti halnya dengan standart memelihara tujuan hukum dan 
keterbukaan tentang kepentingan hukum merupakan yang diinginkan para pihak apabila menyelesaikan sengketanya di Pengadilan. ${ }^{16}$

Pertimbangan hakim dalam putusannya adalah berdasarkan pada pembuktian yaitu berdasarkan keterangan-keterangan dari saksi dan bukti surat. Putusan hakim berdasarkan pada gugatan yang berdasarkan hukum. Kebenaran dan yang dicari dan diwujudkan selain berdasakan alat bukti yang sah dan mencapai batas minimal pembuktian, kebenaran itu harus diyakini hakim. Kebenaran yang diwujudkan benarbenar berdasarkan bukti-bukti yang tidak dapat diragukan, sehingga kebenaran itu dianggap bernilai sebagai kebenaran yang hakiki.

Berdasarkan duduk perkara yang telah diuraian diatas dapat disimpulkan bahwa, pada awalnya pihak suami keberatan terhadap pembagian harta bersama oleh Hakim Mahkamah Syariah Lhoksukon yang membagi 1/3 bagian untuk suami dan 2/3 bagian untuk isteri. Pihak suami merasa putusan hakim Mahkamah Syariah Lhoksukon tersebut tidak adil dan tidak seharusnya demikian, karena sewajarnya harta bersama dibagi dua antara suami dan istri yang bercerai. Oleh karenanya pihak suami mengajukan banding kepada Mahkamah Syariah Banda Aceh, dimana hakim Mahkamah Syariah Banda Aceh memutuskan bahwa pembagian harta bersama untuk $1 / 2$ bagian untuk isteri dan $1 / 2$ bagian untuk suami. Namun pihak isteri merasa keberatan dengan keputusan yang diambil oleh Hakim Mahkamah Syariah Banda Aceh tersebut. Dengan demikian pihak isteri mengajukan kasasi pada Mahkamah Agung. Putusan terakhir Mahkamah Agung sebagaimana tersebut dalam amar putusan di atas menetapkan pihak suami berhak memiliki $1 / 3$ (satu pertiga) bagian dari harta bersama, sedangkan pihak isteri berhak memiliki 2/3 (dua pertiga) bagian dari harta bersama.

Keputusan hakim Mahkamah Syariah Banda Aceh berbeda dengan kedua putusan hakim Mahkamah Syariah Lhoksukon dan hakim Mahkamah Agung. Putusan yang diambil oleh hakim Mahkamah Syariah Lhoksukon dan Mahkamah Agung didasari atas kondisi perkawinan yang telah diperhatikan sebelumnya oleh hakim, dimana adanya keterangan dari saksi serta bukti-bukti bahwa pihak suami tidak melaksanakan kewajibannya sebagai suami yang seharusnya memenuhi kebutuhan di dalam rumah tangga.

Pertimbangan hukum majelis hakim Mahkamah Agung memberikan porsi yang lebih banyak kepada istri dalam pembagian harta bersama karena istri selain mengurus rumah tangga juga mencari nafkah yang seharusnya menjadi kewajiban suami sebagai kepala rumah tangga. Selain itu, Majelis hakim Mahkamah Agung menimbang bahwa adanya beban ganda (double burden) terhadap istri sebagai ibu rumah tangga dan pencari nafkah, maka tidak adil apabila harta bersama dibagi setengah sama banyak antara suami dan istri.

Dalam berumah tangga sudah menjadi kewajiban suami untuk memenuhi segala kebutuhan istrinya, dan istri sudah barang tentu memiliki hak untuk mendapatkan apa yang seharusnya didapatkan oleh istri. Sebagaimana yang diatur dalam Pasal 80 ayat (4) huruf a KHI menyatakan: "Bahwa kewajiban seorang suami terhadap istrinya adalah nafkah, kiswah, dan tempat kediaman bagi istri." Mengenai kewajiban suami dalam memberi nafkah juga terdapat dalam dalam A1-Qur'an Surat Al-Baqarah ayat 233, yang terjemahannya adalah "...dan kewajiban ayah menanggung nafkah dan pakaian mereka dengan cara yang maaruf. Dikarenakan tidak memenuhi nafkah dan kewajiban tersebut

\footnotetext{
${ }^{16}$ Ali Zainudin, 2009, Filsafat Hukum, Gramedia Pustaka Utama, Jakarta, hlm. 67
} 
hakim Mahkamah Agung kemudian memutuskan untuk membagi 1/3 dan 2/3 bagian dari harta bersama.

Putusan Mahkamah Agung Nomor $597 \mathrm{~K} / \mathrm{Ag} / 2016$ yang tidak memutuskan membagi harta bersama masing-masing antara suami dan isteri berhak $1 / 2$ (seperdua), bahkan Mahkamah Agung memutuskan dalam pembagian harta bersama tersebut yaitu $2 / 3$ untuk isteri dan $1 / 3$ untuk suami, dengan pertimbangan hukum sejauh mana kontribusi masing-masing dalam membentuk harta bersama tersebut terlihat kontradiksi dengan aturan yang terdapat pada Pasal 97 KHI dan Pasal 128-129 KUHPerdata yang menyatakan janda dan duda mendapatkan bagian yang sama banyak yaitu masingmasingnya mendapat $1 / 2$ (seperdua) bagian. Dalam hal kasus ini ternyata isteri lebih besar kontribusinya dalam menghasilkan harta bersama tersebut, sehingga wajar apabila bagian isteri lebih besar (2/3) dibanding bagian suami (1/3).

Namun berbeda dengan pertimbangan hakim Mahkamah Syariah Banda Aceh yang dalam putusannya pada tingkat banding Nomor 9/Pdt.G/2016//MS-Aceh menetapkan $1 / 2$ bagian untuk isteri dan $1 / 2$ bagian untuk suami dengan pertimbangan bahwa dari segi legal justice kedudukan suami atau isteri sama dimuka hukum. Suami dan isteri samasama masih berfungsi, walaupun pekerjaan mereka dalam bentuk yang berbeda, yaitu pekerjaan suami tidak seperti isteri yang bekerja sebagai Pegawai Negeri Sipil, namun secara moral suami mempunyai tanggung jawab sebagai pemberi motivasi, pelindung, dan pendamping bagi isteri atau setidaknya telah mendapat restu/izin dari suami dalam hal isteri melaksanakan profesi karirnya sebagai bidan atau kegiatan lainnya. Maka oleh karena itu azas contra legem sebagaimana yang diterapkan dalam perkara in cassu dipandang oleh hakim Mahkamah Syariah Banda Aceh belum tepat. Perkawinan yang dilangsungkan oleh kedua pihak pun tidak ada suatu perjanjian apapun yang dibuat terhadap harta bersama, dengan demikian dalam menentukan porsi atau bagian dari harta bersama haruslah berpedoman pada ketentuan yang terdapat dalam Pasal 37 Undang-Undang perkawinan jo Pasal $97 \mathrm{KHI}$ yaitu masing-masing memperoleh porsi $1 / 2$ bagian dari harta bersama. ${ }^{17}$

Seperti yang diketahui juga bahwa berdasarkan Pasal 35 ayat (1) "harta benda yang diperoleh selama perkawinan menjadi harta bersama" dan berdasarkan Pasal 1 huruf (f) KHI "harta kekayaan dalam perkawinan atau syirkah adalah harta yang diperoleh baik sendiri-sendiri atau bersama suami-isteri selama dalam ikatan perkawinan berlangsung selanjutnya disebut harta bersama tanpa mempersoalkan terdaftar atas nama siapapun", maka dapat disimpulkan bahwa siapapun yang menghasilkan harta bersama dalam masa perkawinan harta tersebut menjadi harta bersama tanpa mempersoalkan siapa yang menghasilkannya.

Namun dalam putusan Nomor $597 \mathrm{~K} / \mathrm{Ag} / 2016$, Hakim Mahkamah Agung lebih mempertimbangkan pada sosial justice yaitu mengenai andil/usaha para pihak, yang mana hal ini dapat diartikan bahwa hakim tidak serta merta membagi rata bagian yang diberikan untuk para pihak, tetapi ia menilai dari bagaimana keadaan para pihak di dalam rumah tangganya serta usaha para pihak dalam rumah tangganya. Dalam fakta persidangan pun menyebutkan bahwa isteri juga lebih dahulu bekerja dan sebagian besar harta diperoleh dari hasil kerja isteri, sehingga di nilai tidak adil bila isteri yang membiayai segala keperluan rumah tangganya dan bahkan dapat menghasilkan harta bersama dalam perkawinan, selain itu juga walaupun posisi suami secara moral

${ }^{17}$ Rafi'Uddin, Hakim Anggota Mahkamah Syari'ah Aceh, wawancara, tanggal 22 April 2019, Pukul 11.00 WIB. 
bertanggung jawab sebagai pemberi motivasi, pelindung dan pendamping bagi isteri atau setidaknya telah mendapat izin/restu suami dalam hal isteri melaksanakan profesi karirnya sebagai bidan atau kegiatan lainnya, namun hal tersebut tidak dapat dijadikan dalil untuk dapat memberikan hak yang sama terhadap harta bersama yang sebagian besar atas kerja keras isteri.

Pihak suami tidak seharusnya menuntut pembagian porsi harta bersama yang umumnya terjadi, yakni $1 / 2$ bagian untuk masing-masing pihak. Suami sepatutnya menyadari bahwa kewajibannya sebagai suami seharusnya dilaksanakan terlebih dahulu baru kemudian ia dapat menuntut apa yang menjadi haknya. Suami diketahui mengabaikan kewajibannya dan menganggap remeh untuk memberikan nafkah pada istri dan anak-anaknya. Sikap suami yang demikian tentu tidak sesuai dengan apa yang seharusnya dilakukan oleh seorang pemimpin dalam rumah tangga. Memberi nafkah dan mencukupi kewajiban dalam rumah tangga memang menjadi kewajiban bagi suami, sehingga dengan melaksanakannnya tercapailah bentuk tanggung jawab yang tidak hanya diperuntukkan bagi keluarga saja, tetapi lebih jauh lagi kepada Allah SWT.

Hakim Mahkamah Agung sependapat dengan hakim Mahkamah Syariah Lhoksukon yang menerapkan asas contra legem dalam pertimbangan nya untuk memutusakan perkara tersebut, sehingga hakim Mahkamah Agung mengambil alih pertimbangan tersebut sebagai pertimbangan sendiri. Hakim di sini juga mempertimbangkan dengan memasukkan Pasal 229 Kompilasi Hukum Islam yang isinya menyatakan "hakim dalam menyelesaikan perkara-perkara yang diajukan kepadanya wajib memperhatikan dengan sungguh-sungguh nilai-nilai hukum yang hidup dimasyarakat sehinnga putusannya sesuai dengan rasa keadilan”. Ketentuan Pasal ini juga sejalan dengan aturan dalam Undang-Undang Nomor 48 Tahun 2009 tentang kekuasaan kehakiman Pasal 5 ayat (1) dimana dinyatakan "hakim dan hakim konstitusi wajib mengali, mengikuti, dan memahami nilai-nilai hukum dan rasa keadilan yang hidup dalam masyarakat."

Apabila dikaitkan dengan teori keadilan, pengadilan dalam membuat putusan selalu diawali dengan: "Demi Keadilan Berdasarkan Ketuhanan Yang Maha Esa", jadi yang ditegakkan oleh pengadilan adalah "keadilan" bukan "Demi hukum". Beda antara demi keadilan dengan demi hukum, sebab ruh hukum adalah keadilan. Keadilan dalam hal ini dimaknai memberikan kepada setiap orang apa yang menjadi haknya. ${ }^{18}$

Aristoteles mengemukakan keadilan itu sebagai suatu pemberian hak persamaan tapi bukan persamarataan. Aristoteles membedakan hak persamaannya sesuai dengan proposional artinya kesamaan proposional memberi tiap orang apa yang menjadi hak nya sesuai dengan kemampuan dan prestasi yang telah dilakukannya. Keadilan menurut Aristoteles di bagi menjadi dua macam keadilan yaitu keadilan distributif dan keadilan commutatief. ${ }^{19}$

Konsep pembagian harta bersama berdasarkan kontribusi dalam perkawinan berhubungan dengan teori keadilan distributif dari Aristoteles (justisia distributive), yaitu : "Bahwa keadilan adalah memberikan bagian kepada setiap orang didasarkan atas jasa-jasanya atau kontribusinya. Dalam arti bahwa keadilan yaitu membagi sesuatu secara proporsional bukan membagi sama rata. ${ }^{20}$ Jika dikaitkan dengan putusan hakim

\footnotetext{
${ }^{18}$ Akhmad Khisni, 2012, Ijtihad Progresif dalam Penegakan Hukum Positif Islam di Pengadilan Agama tentang Pembagian Harta Bersama, Jurnal Hukum IUS QUIA IUSTUM, No. 3 Vol. 19, hlm. 7

${ }^{19}$ Pan Mohamad Faiz, 2009, Teori Keadilan John Rawls, Jurnal Konstitusi, Vol. 6 No. 1, hlm. 9

${ }^{20}$ Mahir Amin, 2014, Konsep Keadilan Dalam Perspektif Filsafat Hukum Islam, Al-Daulah: Jurnal Hukum Dan Perundangan Islam, Vol. 4, No. 2, Oktober hlm. 8
} 
Mahkamah Agung tersebut unsur keadilan dalam putusan 597 K/AG/2016 telah terpenuhi, karena berdasarkan fakta dipersidangan pihak isteri yang lebih memiliki kontribusi dalam menghasilkan harta bersama dan pihak isteri lebih dulu bekerja dan sebagian besar harta diperoleh dari hasil kerja pihak isteri. Dalam harta bersama, istri yang mempunyai kontribusi yang lebih besar dari suami sudah seharusnya mendapatkan bagian harta bersama yang lebih banyak dari suami.

Konsep pembagian harta bersama berdasarkan kontribusi dalam perkawinan memberikan ruang bagi hakim untuk menggali nilai-nilai keadilan di masyarakat dan membuat putusan yang merefleksikan nilai-nlai keadilan substantif yang merupakan salah satu pesan konstitusi dalam menegakkan prinsip keadilan dalam proses peradilan. Hakim tidak hanya "la bauche de la loi" (corong undang-undang), hakim harus menggali dengan pikirannya untuk menemukan hukumnya dalam menangani kasus yang ditanganinya, sehingga dapat memutus dengan putusan yang adil. ${ }^{21}$

Sedangkan berdasarkan keadilan commucatief, dimana keadilan tersebut menyebutkan bahwa memberikan sama banyaknya kepada setiap orang tanpa membedabedakan prestasinya, dalam hal ini bearti pembagian harta bersama tersebut haruslah di bagi sama rata yaitu $1 / 2$ untuk isteri dan $1 / 2$ siapapun yang menghasilkan harta bersama tersebut. Pembagian harta bersama yang sama rata tersebut apabila suami isteri memiliki kontribusi yang sama dalam menghasilkan harta bersama maka hakim dalam suatu kasus dapat memutuskan pembagian harta bersama tersebut sama rata antara suami dan isteri.

Suami berkewajiban untuk mencari nafkah untuk keluarganya. Begitupun istri, dalam hal istri tidak bekerja di luar, tetapi dia memiliki peran besar dalam menjaga keutuhan dan kelangsungan keluarganya, seperti mengurusi urusan rumah tangga, mengantar dan menjemput anak, berbelanja dan menyediakan kebutuhan suami, dan sebagainya, maka istri tersebut layak untuk mendapatkan hak separuh harta bersama. Karena status istri yang bekerja di rumah sebagai ibu rumah tangga sebanding dengan suami yang bekerja di luar rumah.

Jika si suami bekerja mencari nafkah dan istri tidak menjalankan kewajibannya mengurus rumah tangga, tidak melayani suami, mendidik anaknya, bahkan melakukan nusyuz terhadap suami, berarti istri tidak memberikan kontribusi yang seimbang dengan suami. Apabila terjadi perceraian maka suami berhak mendapatkan bagian lebih besar dari si istri. Bisa untuk suami $2 / 3$ atau $3 / 4$, sedangkan untuk istri hanya $1 / 3$ atau $1 / 4$. Begitu sebaliknya, apabila yang mencari nafkah si istri bahkan juga mengurus rumah tangga sehingga memberikan beban ganda (double burden) bagi istri. Sedangkan suami tidak menjalankan kewajibannya secara aktif sebagai pencari nafkah, malah tidak mau tahu tentang keuangan rumah tangga.

Apabila terjadi perceraian maka istri berhak mendapatkan bagian lebih besar dari si suami. Bisa untuk istri $2 / 3$ atau $3 / 4$ sedangkan untuk suami hanya $1 / 3$ atau $1 / 4$. Bahkan dalam suatu kasus apabila hakim menemukan fakta-fakta persidangan bahwa suami tidak hanya tidak menjalankan kewajibannya namun juga menyusahkan si istri, melakukan kekerasan dalam rumah tanggga, boros, sering judi maupun mabuk. Hakim dapat memutuskan untuk tidak memberikan bagian harta bersama kepada suami.

\section{SIMPULAN}

${ }^{21}$ Kholil Nawawi, 2013, Harta Bersama menurut Hukum Islam dan Perundang-Undangan di Indonesia, Jurnal Ilmu Syariah, Vol. 1, No. 1, Juni hlm. 7 
Dasar pertimbangan hakim Agung dalam putusan Nomor $597 \mathrm{~K} / \mathrm{Ag} / 2016$ yang menetapkan pembagian harta bersama setelah perceraian bahwa hakim Agung tidak mengikuti ketentuan Pasal 97 KHI, dimana berdasarkan asas keadilan dan sosial justice, hakim Agung menetapkan pembagian untuk istri $2 / 3$ bagian dan suami $1 / 3$ bagian. Hakim diberikan kebebasan untuk menggali nilai-nilai hukum yang hidup di masyarakat. Hakim dalam menangani perkara berusaha tidak sekedar menjadi corong undang-undang. Secara kasuistik pembagian harta bersama yang tidak berdasarkan ketentuan Pasal 97 KHI, karena seharusnya suami yang berperan penting dalam mencari nafkah dan mencukupi kebutuhan rumah tangga, namun suami tidak menjalankan perannya dengan baik dengan kurang bertanggung jawab terhadap kebutuhan rumah tangga, tetapi isterilah yang lebih berperan dalam mencari nafkah dan mendapatkan harta bersama. Sehingga hakimerdasarkan asas keadilan dan sosial justice, menetapkan pembagian untuk istri $2 / 3$ bagian dan suami $1 / 3$ bagian.

\section{DAFTAR PUSTAKA}

\section{Buku}

Ali Zainudin, (2009), Filsafat Hukum, Gramedia Pustaka Utama, Jakarta.

Budi Setiawan Utomo, (2009), Fiqih Aktual, Gema Insani, Jakarta.

Mahdiah, (2011), Permasalahan Perkawinan dan Kewarisan, Cet.1, Pustaka Panjimas, Jakarta.

Sonny Dewi Judiasih, (2015), Harta Benda Perkawinan, Kajian terhadap Kesetaraan Hak dan Kedudukan Suami dan Isteri atas Kepemilikan Harta dalam Perkawinan, Cet. 1, PT Refika Aditama, Bandung.

Titon Slamet Kurnia Dkk, (2013), Pendidikan Hukum, Ilmu Hukum \& Penelitian Hukum Di Indonesia Sebuah Reorientasi, Pustaka Pelajar, Yogyakarta.

Zainuddin Ali, (2010), Metode penelitian Hukum, Cet. 2, Sinar Grafika, Jakarta.

\section{Journal dan karya ilimiah lain}

Agustina Dewi Putri, (2019), Peralihan Harta Bersama Melalui Hibah Tanpa Izin Salah Satu Pihak Berdasarkan Undang-Undang Nomor 1 Tahun 1974 Dan Kompilasi Hukum Islam, Syiah Kuala Law Journal (SKLJ), Vol. 3, No. 1, hal. 6.

Akhmad Khisni, (2012), Ijtihad Progresif dalam Penegakan Hukum Positif Islam di Pengadilan Agama tentang Pembagian Harta Bersama, Jurnal Hukum IUS QUIA IUSTUM, No. 3 Vol. 19, hal. 7.

Bernadus Nagara, (2016), Pembagian Harta Gono-Gini atau Harta Bersama Setelah Perceraian Menurut Undang-Undang Nomor 1 Tahun 1974, Lex Crimen, Vol. 5, No. 7, hal. 2.

Eni C. Singal, (2017), Pembagian Harta Gono-Gini Dan Penetapan Hak Asuh Anak Akibat Perceraian Berdasarkan Undang-undang Nomor 1 Tahun 1974", Lex Crimen, Vol. 6, No. 5, hal. 2.

Evi Djuniarti, (2017), Hukum Harta Bersama Ditinjau Dari Perspektif Undang-Undang Perkawinan dan KUHPerdata, Jurnal Penelitian Hukum DE JURE, Vol. 17 No. 4, hal. 8 . 
Kholil Nawawi, (2013), Harta Bersama menurut Hukum Islam dan PerundangUndangan di Indonesia, Jurnal Ilmu Syariah, Vol. 1, No. 1, hal. 7.

Mahir Amin, (2014), Konsep Keadilan Dalam Perspektif Filsafat Hukum Islam, A1Daulah: Jurnal Hukum Dan Perundangan Islam, Vol. 4, No. 2, hal. 8.

Pan Mohamad Faiz, (2009), Teori Keadilan John Rawls, Jurnal Konstitusi, Vol. 6 No. 1, hal. 9.

Sri Hariati dan Musakir Salat, (2013), "Ketidakadilan Pembagian Harta Gono Gini Pada Kasus Perceraian The Injustice Of Distributing Marital Property", Jurnal IUS, Vol. 1, No. 3, hal. 2.

Sukardi, (2016), "Kajian Yuridis Perjanjian Perkawinan Menurut Kitab Undang-Undang Hukum Perdata, Undang-Undang Nomor 1 Tahun 1974 dan Kompilasi Hukum Islam", Jurnal Khatulistiwa - Journal of Islamic Studies, Vol. 6, No. 1, hal. 65

Syaikhul Hakim, (2015), "Reaktualisasi Pembagian Harta Bersama Dalam Mazhab Syafii Dan Kompilasi Hukum Islam Di Indonesia", Akademika, Vol. 9, No. 2, hal. 45

\section{Wawancara}

Rafi'uddin, Hakim Anggota Mahkamah Syari'ah Aceh, wawancara, tanggal 22 April 2019, Pukul 11.00 WIB.

\section{Peraturan Perundang-Undangan}

Undang-Undang Dasar Negara Republik Indonesia Tahun 1945

Undang-Undang Nomor 1 Tahun 1974 Tentang Perkawinan (Lembaran Negara Republik Indonesia Tahun 1974 Nomor 1 Tambahan Lembaran Negara Republik Indonesia Nomor 301)

Undang-Undang Republik Indonesia Nomor 12 Tahun 2011 tentang Pembentukan Peraturan Perundangan-undangan (Lembaran Negara Republik Indonesia Tahun 2011 Nomor 82 Tambahan Lembaran Negara Republik Indonesia Nomor 5234)

Peraturan Pemerintah Republik Indonesia Nomor 9 Tahun 1975 Tentang pelaksanaan Undang-Undang Nomor 1 Tahun 1974 Tentang perkawinan (Lembaran Negara Republik Indonesia Tahun 1975 Nomor 12 Tambahan Lembaran Negara Republik Indonesia Nomor 3250)

Instruksi Presiden Republik Indonesia Nomor 1 Tahun 1991 Tentang Penyebarluasan Kompilasi Hukum Islam. 